\title{
Influence of larning interest and vocabulary on the writing description of secondary school in Depok
}

\author{
Dwi Septiani *), \\ Universitas Pamulang \\ *) Correspondences author: Jalan Surya Kencana No.1, Pamulang, Kota Tangerang Selatan, Banten 15417; Indonesia \\ e-mail: dosen01401@unpam.ac.id.
}

\begin{abstract}
The purpose of this research: (1) to know the influence of the interaction of learning interest and mastery of the standard vocabulary together to the ability to write the description of the students of SMPN in Depok. (2) to know the effect on the ability to write the description of SMPN students in Depok. (3) to know the influence of standard vocabulary mastery to the ability to write the description of SMPN students in Depok. The research method used is survey method with multiple correlation regression analysis. The sample of the research is the students of class VII: SMPN 1 Depok and SMPN 2 Depok as many as 80 students and take a simple random technique. Data collection was done by direct questionnaire to sample. Data analysis uses descriptive statistics, such as searching for mean (mean), median, mode, standard deviation, and inferential statistics, ie to find simple and double correlation coefficients followed by correlation coefficient significance test with t test. The findings of the researcher indicate that: (1) there is a significant influence of learning interest and mastery of the standard vocabulary simultaneously to the ability to write student description with the acquisition value $\mathrm{Fo}=21,909$ and $\mathrm{Sig} .=0,000<0.05 ;(2)$ there is a significant influence of learning interest on the ability to write student description with thitung $(3,564)>t$ table $(1,99)$ and Sig. $0.001<0.05$; $(3)$ there is a significant influence of vocabulary mastery of the learning achievement on the subject of writing description. This is evidenced by the value of thitung (5.909) $>$ t table (1.99) and Sig. $0,000<0.05$.
\end{abstract}

Key Words: Interest in Learning, Vocabulary, Writing Description.

Article History: Received: 29/10/2017; Revised: 30/11/2017; Accepted: 05/12/2017; Published: 20/12/2017

How to Cite (MLA $7^{\text {th }}$ ): Septiani, Dwi. "Influence of larning interest and vocabulary on the writing description of secondary school in Depok." Hortatori Jurnal Pendidikan Bahasa dan Sastra Indonesia 1.2 (2017): 169-178. Print/Online. Copyrights Holder: Septiani, Dwi. First Publication: Hortatori Jurnal Pendidikan Bahasa dan Sastra Indonesia (2017).

This work is licensed under a Creative Commons Attribution-ShareAlike 4.0 International License.

\section{Pendahuluan}

Semua warga negara Indonesia wajib membina dirinya masing-masing dalam pemakaian bahasa Indonesia agar bahasa itu tumbuh dan berkembang sesuai dengan kaidah yang berlaku. Oleh karena itu, pembina pendidikan, terutama guru bahasa Indonesia harus selalu berupaya menumbuhkan minat belajar siswa pada pelajaran Bahasa dan Sastra Indonesia di sekolah. Dalam Menulis sebagai Suatu Keterampilan Berbahasa, menurut Tarigan (2008: 2), kemampuan berbahasa umumnya memiliki empat komponen, yakni keterampilan menyimak (listening skills), keterampilan berbicara (speaking skills), keterampilan membaca (reading skills), dan keterampilan menulis (writing skills). Jika sudah dapat memahami keempat aspek tersebut, dapat dikatakan bahwa siswa berhasil dalam pembelajaran kebahasaan. Salah satu kemampuan yang masih sangat rendah dikuasai oleh siswa umumnya adalah kemampuan menulis.

Akhadiah dkk. (1993: 143) mengatakan bahwa "kemampuan menulis bukanlah kemampuan yang diwariskan secara turun-temurun, tetapi merupakan hasil proses belajar-mengajar dan ketekunan berlatih." Pendapat lain, Badudu dan Zain (1996: 1547) pengertian menulis jauh lebih sederhana, yakni menurut adalah menggunakan pena, potlot, bolpoin di atas kertas, kain, atau papan, dan sebagainya untuk 
menghasilkan huruf, kata, atau kalimat. Secara umum, menulis dilaksanakan dengan mengikuti tujuh langkah: (1) pemilihan dan penetapan topik, (2) pengumpulan informasi, (3) penetapan tujuan, (4) perancangan tulisan, (5) penulisan, (6) penyuntingan atau revisi, (7) penulisan naskah jadi (Semi, 1990: 11). Kemampuan menulis dapat dicapai dengan bimbingan yang sistematis serta latihan yang intensif.

Berdasarkan dari pengertian di atas, menulis atau mengarang merupakan pengungkapan pikiran, ide, dan perasaan melalui lambang grafis, atau simbol yang sistematis. Dengan menulis, seseorang tidak hanya menggambarkan satu pemikiran, tetapi juga dapat berkomunikasi serta menggunakan kosakata dan struktur bahasa dalam bentuk tulisan yang dapat dipahami oleh orang lain. Salah satu kegiatan menulis yang umumnya dipakai oleh pengajar atau guru untuk tahap awal adalah teks berjenis deskripsi.

Kata deskripsi berasal dari kata latin describere yang berarti menulis tentang, atau mebeberkan sesuatu hal. Selain itu, kata deskripsi dapat diterjemahkan menjadi pemerian, yang barasal dari kata perimemerikan yang berarti "melukiskan sesuatu hal". Pengertian teks berkaitan erat dengan pengertian wacana. Gillian Brown dan George Yule dalam Okke Zaimar dan Ayo B. Harahap (2011: 14) menyatakan bahwa teks adalah realisasi wacana dan menganggap teks sebagai rekaman verbal suatu tindak komunikasi. Di sisi lain, menurut Suherli (2007: 10), karangan deskripsi menyajikan suatu peristiwa atau objek hasil pengindraan dengan cara melukiskan, menggambarkan, atau memerikan sehingga pembaca seperti menyaksikan, mengindra, atau mengalami sendiri secara langsung.

Menurut Keraf (2007:93), karangan deskripsi merupakan sebuah bentuk tulisan yang bertahan dengan usaha para penulis untuk memberikan perincian-perincian dan objek yang sedang dibicarakan. Dari pengertian di atas, dapat disimpulkan bahwa tulisan deskripsi adalah pelukisan objek yang kasatmata. Deskripsi merupakan bentuk pengembangan paragraf yang bertujuan melukiskan sesuatu seolah-olah pembaca dapat mencintrai yang dilukiskan oleh penulisnya. Pembaca pun dituntut untuk dapat berimajinasi seolah-olah mereka melihat, mendengarkan, dan merasakan apa yang penulis lukiskan dalam bentuk tulisan.

Dalam proses menguasai keterampilan menulis, siswa atau pelajar haruslah memiliki minat belajar serta kemampuan dalam menggunakan berbagai kosakata baku. Kedua hal tersebut berpengaruh secara langsung dengan kualitas karya tulis yang dihasilkan nantinya. Seorang siswa atau pelajar wajib memiliki minat belajar. Minat (interest) adalah kecenderungan seseorang untuk melakukan sesuatu perbuatan (Mulyasa, 2002: 38). Setiap individu tidak akan melakukan kegiatan apa pun jika ia tidak memiliki minat sama sekali. Akan tetapi, sebaliknya, seseorang akan sanggup menempuh berbagai rintangan untuk melakukan sesuatu demi mewujudkan minat dalam pikirannya jika memiliki minat yang besar.

Soekamto (1991: 59-60) mengatakan bahwa minat berhubungan dengan segi-segi psikologis yang lain, seperti perhatian, ketertarikan, motivasi, dan sikap. Namun, dalam kehidupan remaja, bentuk minat dan cita-cita sangat beragam. Sebagaimana pendapat Mappiare (1992: 63) tentang bentuk minat di masa remaja, yaitu beberapa bentuk minat dan cita-cita yang penting dan menonjol dapat dikelompokkan dalam minat pribadi dan minat sosial, minat terhadap rekreasi, minat terhadap agama, serta minat terhadap cita-cita pendidikan dan jabatan. Cita-cita adalah perwujudan dari minat dalam hubungan dengan masa depan yang direncanakan seseorang, terkait dengan menentukan pilihan terhadap pendidikan, pekerjaan teman hidup, dan sebagainya.

Minat dan cita-cita pada remaja banyak dipengaruhi oleh adanya faktor dari orang tua maupun dari minat kelompoknya. Dari uraian di atas, penulis menyimpulkan bahwa hakikat minat adalah kekuatan, kecondongan, kegairahan yang menyebabkan individu menaruh perhatian yang besar dan merelakan dirinya terikat terhadap sesuatu yang disukainya untuk mencapai tujuan sehingga menimbulkan rasa puas. Minat dapat muncul dari dalam diri individu karena kebutuhannya. Selain itu, minat dapat juga timbul dari pengaruh-pengaruh eksternal yang berupa respons seseorang yang diwujudkan dengan tindakan.

Selain minat belajar, penguasaan kosakata baku pun ikut berperan dalam menentukan kualitas teks deskriptif yang dibuat. Kosakata (lexicon) adalah komponen bahasa yang memuat semua informasi tentang makna dan pemakaian kata. Dengan demikian, semua kata dasar, kata berimbuhan, kata berulang, dan kata majemuk dalam bahasa Indonesia dapat disebut sebagai kosakata bahasa Indonesia. Kosakata pun merupakan kata-kata yang dikuasai oleh seorang atau segolongan orang dalam lingkungan yang sama. Hal ini artinya kosakata yang dikuasai oleh seseorang dalam suatu lingkungan berbeda dengan lingkungan lainnya.

Kata baku adalah suatu bentuk pemakaian bahasa yang menjadi model yang dapat dicontoh oleh setiap pemakaian bahasa yang hendak berbahasa secara benar (Moeliono, 1989: 23). Lebih lanjut, Moeliono 
(1989: 43) juga memaparkan bahwa kata baku standar adalah ragam bahasa yang berkekuatan sanksi sosial dan yang diterima masyarakat bahasa sebagai acuan atau model.

Dari beberapa penjelasan di atas, dapat disimpulkan bahwa kosakata baku bahasa Indonesia adalah kosakata yang digunakan baik secara tertulis maupun diucapkan oleh sebagian besar masyarakat (lazim dan berterima) dalam situasi pemakaian bahasa yang bersifat resmi. Selain itu, kosakata baku bahasa Indonesia juga dapat menjadi acuan norma berbahasa Indonesia yang baik dan benar bagi penutur bahasa Indonesia. Dari paparan teori variabel penelitian di atas, peneliti melakukan pengkajian tentang pengaruh minat belajar dan penguasaan kosata baku terhadap kemampuan menulis deskripsi siswa SMPN di Depok.

\section{Metode}

Metode penelitian ini adalah cara yang digunakan dalam mengumpulkan data penelitian adalah dengan menggunakan metode survey (Sugiono, 2008: 7) dengan analisis korelasi regresi ganda. Desain ini digunakan untuk meneliti dua variabel bebas terhadap satu veriabel terikat. Data-data dalam penelitian ini diperoleh berdasarkan angket minat belajar dan penguasaan kosakata baku serta pemberian instrumen pada materi kemampuan menulis teks deskriptif siswa kelas VII SMP Negeri di Depok.

Populasi target adalah siswa kelas VII SMPN di Depok sebanyak 785 siswa. Sampel ditetapkan sebesar $10 \%$ dari total populasi, yaitu 78,5 atau dibulatkan dengan total 80 siswa. Jadi, sebanyak 40 orang diambil dari kelas VII siswa SMP Negeri 1 Depok dan 40 orang diambil dari kelas VII siswa SMP Negeri 2 Depok.

Variabel pertama adalah minat belajar siswa $\left(\mathrm{X}_{1}\right)$. Yang dimaksud dalam minat belajar adalah kecenderungan hati yang terarah yang dapat timbul dari dalam dan dari luar diri setiap orang terhadap sesuatu objek, mempunyai kesiapan reaktif untuk memberikan perhatian, rela mengorbankan waktu, tenaga dan uang, serta mendorong untuk berbuat dengan rasa senang, karena ada kepentingan dari apa yang diperhatikannya.

Nilai yang diperoleh oleh siswa untuk minat belajar diukur dengan tes minat diri sebanyak 30 butir pertanyaan yang mencerminkan ketaatan, pemanfaatan waktu, perhatian, dan keinginan. Skor minat belajar diperoleh dari jumlah skor 30 butir pernyataan yang direspons oleh 80 siswa. Instrumen yang digunakan untuk mengumpulkan data minat belajar berbentuk kuesioner dengan menggunakan rating scale. Model rating scale yang digunakan dalam bentuk kontinum dengan lima kategori.

\begin{tabular}{|l|l|l|l|l|l|}
\hline Skrtanyaan & $\begin{array}{l}\text { Sangat } \\
\text { setuju }\end{array}$ & Setuju & Ragu-ragu & Tidak setuju & $\begin{array}{l}\text { Sangat tidak } \\
\text { setuju }\end{array}$ \\
\hline Positif & 5 & 4 & 3 & 2 & 1 \\
\hline Negatif & 1 & 2 & 3 & 4 & 5 \\
\hline
\end{tabular}

Pengujian validitas dan perhitungan reliabilitas, sebelum digunakan untuk menjaring data penelitian atau digunakan pada subjek penelitian. Instrumen minat belajar siswa perlu dikalibrasi agar diketahui tingkat keandalan instrumen. Maka dari itu, dilakukan uji coba instrumen minat belajar siswa kelas VII SMPN di Depok. Tujuan uji coba instrumen minat belajar ini adalah untuk melihat validitas butir dan reliabilitas instrumen. Pengujian validitas butir instrumen menggunakan rumus Korelasi product moment sesuai dengan Arikunto (2010: 213). Sebagai berikut:

$$
\begin{aligned}
\mathrm{r}_{\text {hitung }} & =\frac{N \sum X Y-\left(\sum X\right)\left(\sum Y\right)}{\sqrt{\left(N \sum X^{2}-\left(\sum X\right)^{2}\right)\left(N \sum Y^{2}-\left(\sum Y\right)^{2}\right)}} \\
\text { Keterangan: } & \\
\mathrm{r}_{\mathrm{xy}} & =\text { Koefesien korelasi } \\
\mathrm{N} & =\text { Jumlah responden } \\
\mathrm{X} & =\text { Skor butir yang dihitung validitasnya } \\
\mathrm{Y} & =\text { Skor total }
\end{aligned}
$$

Untuk interpretasi dalam menentukan butir valid atau tidak, selanjutnya nilai $r_{\mathrm{xy}}$ atau $\mathrm{r}_{\text {hitung }}$ tersebut dikonsultasikan dengan nilai $r_{\text {tabel }}$ pada $\alpha=0,05$ dengan ketentuan $r_{\text {hitung }}>r_{\text {tabel }}$ maka butir dinyatakan valid dan jika $\mathrm{r}_{\text {hitung }}<\mathrm{r}_{\text {tabel }}$ maka butir dinyatakan tidak valid.

Hasil pengujian diperoleh 30 butir pertanyaan dinyatakan valid dan 4 butir pertanyaan tidak valid. Peneliti membuang 4 butir pertanyaan yang tidak valid. Data hasil uji validitas instrumen minat belajar sebagai berikut: 


\begin{tabular}{|l|l|l|l|}
\hline No Soal & \multicolumn{1}{|l|}{$\mathrm{r}_{\text {hitung }}$} & $\mathrm{r}_{\text {tabel }}$ & Validitas \\
\hline 1 & 0,397 & 0,396 & $\mathrm{~V}$ \\
\hline 2 & 0,424 & 0,396 & $\mathrm{TV}$ \\
\hline 3 & 0,366 & 0,396 & $\mathrm{TV}$ \\
\hline 4 & 0,387 & 0,396 & $\mathrm{~V}$ \\
\hline 5 & 0,417 & 0,396 & $\mathrm{~V}$ \\
\hline 6 & 0,521 & 0,396 & $\mathrm{~V}$ \\
\hline 7 & 0,482 & 0,396 & $\mathrm{~V}$ \\
\hline 8 & 0,521 & 0,396 & $\mathrm{~V}$ \\
\hline 9 & 0,462 & 0,396 & $\mathrm{~V}$ \\
\hline 10 & 0,531 & 0,396 & $\mathrm{~V}$ \\
\hline 11 & 0,375 & 0,396 & $\mathrm{TV}$ \\
\hline 12 & 0,434 & 0,396 & $\mathrm{TV}$ \\
\hline 13 & 0,426 & 0,396 & $\mathrm{~V}$ \\
\hline 14 & 0,426 & 0,396 & $\mathrm{~V}$ \\
\hline 15 & 0,450 & 0,396 & $\mathrm{~V}$ \\
\hline
\end{tabular}

\begin{tabular}{|l|l|l|l|}
\hline No Soal & $\mathrm{r}_{\text {hitung }}$ & $\mathrm{r}_{\text {tabel }}$ & Validitas \\
\hline 16 & 0,436 & 0,396 & $\mathrm{~V}$ \\
\hline 17 & 0,492 & 0,396 & $\mathrm{~V}$ \\
\hline 18 & 0,479 & 0,396 & $\mathrm{~V}$ \\
\hline 19 & 0,614 & 0,396 & $\mathrm{~V}$ \\
\hline 20 & 0,441 & 0,396 & $\mathrm{~V}$ \\
\hline 21 & 0,688 & 0,396 & $\mathrm{~V}$ \\
\hline 22 & 0,353 & 0,396 & $\mathrm{TV}$ \\
\hline 23 & 0,335 & 0,396 & $\mathrm{TV}$ \\
\hline 24 & 0,668 & 0,396 & $\mathrm{~V}$ \\
\hline 25 & 0,503 & 0,396 & $\mathrm{~V}$ \\
\hline 26 & 0,563 & 0,396 & $\mathrm{~V}$ \\
\hline 27 & 0,398 & 0,396 & $\mathrm{~V}$ \\
\hline 28 & 0,584 & 0,396 & $\mathrm{~V}$ \\
\hline 29 & 0,413 & 0,396 & $\mathrm{~V}$ \\
\hline 30 & 0,514 & 0,396 & $\mathrm{~V}$ \\
\hline
\end{tabular}

Untuk pengujian reliabilitas instrumen minat belajar digunakan reliabilitas internal consistency dengan rumus Alfa Cronbach (Sugiyono, 2012: 365) Sebagai berikut:

$\mathrm{r}_{11}=\frac{k}{k-1}\left[1-\frac{\sum S 1^{2}}{S t^{2}}\right]$

Keterangan

$\mathrm{r}_{11} \quad=$ reliabilitas instrumen secara keseluruhan

$\mathrm{k} \quad=$ jumlah butir

$\sum \mathrm{S}^{2}=$ Jumlah varian dari skor tiap butir

$\mathrm{St}^{2} \quad=$ varians skor total

Untuk menentukan apakah koefesien reliabilitas yang diperoleh memenuhi syarat atau tidak, maka mengacu pada Sudijono (2011: 267) yaitu:

a) Jika $r_{11} \geq 0,308$ berarti instrumen minat belajar yang diujikan reliabilitasnya tinggi.

b) Jika $r_{11} \leq 0,308$ berarti instrumen minat belajar yang diujikan reliabilitasnya rendah.

Berdasarkan Tes Reliabilitas dengan Alpha Cronbach Minat Belajar Bahasa Indonesia ( $\left.\mathrm{X}_{1}\right)$

\begin{tabular}{|c|c|}
\hline \multicolumn{2}{|c|}{ Reliability Statistics } \\
\hline Cronbach's Alpha & N of Items \\
\hline .883 & 30 \\
\hline
\end{tabular}

Note: $\mathrm{r}$-tabel $=0,396 ; \mathrm{db}=25 ; \alpha=0,05$

Nilai alpha cronbach > r-tabel maka instrumen dapat dikatakan reliable.

Oleh karena itu, dapat disimpulkan bahwa instrumen minat belajar memiliki tingkat reliabilitas yang tinggi dan dapat digunakan untuk mengukur dapat penelitian.

Selain menguji instrumen minat belajar $\left(\mathrm{X}_{1}\right)$, peneliti melakukan uji validitas dan reabilitas pada instrumen penguasaan kosakata baku $\left(\mathrm{X}_{2}\right)$. Hasil pengujian diperoleh 30 butir pertanyaan dinyatakan valid dan 6 butir pertanyaan tidak valid. Peneliti membuang 6 butir pertanyaan yang tidak valid. Data hasil uji validitas instrumen penguasaan kosakata baku sebagai berikut:

\begin{tabular}{|l|l|l|l|}
\hline No Soal & $\mathrm{r}_{\text {hitung }}$ & $\mathrm{r}_{\text {tabel }}$ & Validitas \\
\hline 1 & 0,478 & 0,396 & $\mathrm{~V}$ \\
\hline
\end{tabular}

\begin{tabular}{|l|l|l|l|}
\hline No Soal & $\mathrm{r}_{\text {hitung }}$ & $\mathrm{r}_{\text {tabel }}$ & Validitas \\
\hline 16 & 0,471 & 0,396 & $\mathrm{~V}$ \\
\hline
\end{tabular}




\begin{tabular}{|l|l|l|l|}
2 & 0,531 & 0,396 & $\mathrm{~V}$ \\
\hline 3 & 0,385 & 0,396 & $\mathrm{TV}$ \\
\hline 4 & 0,471 & 0,396 & $\mathrm{~V}$ \\
\hline 5 & 0,502 & 0,396 & $\mathrm{~V}$ \\
\hline 6 & 0,375 & 0,396 & $\mathrm{TV}$ \\
\hline 7 & 0,435 & 0,396 & $\mathrm{~V}$ \\
\hline 8 & 0,353 & 0,396 & $\mathrm{TV}$ \\
\hline 9 & 0,569 & 0,396 & $\mathrm{~V}$ \\
\hline 10 & 0,420 & 0,396 & $\mathrm{~V}$ \\
\hline 11 & 0,499 & 0,396 & $\mathrm{~V}$ \\
\hline 12 & 0,368 & 0,396 & $\mathrm{TV}$ \\
\hline 13 & 0,432 & 0,396 & $\mathrm{~V}$ \\
\hline 14 & 0,424 & 0,396 & $\mathrm{~V}$ \\
\hline 15 & 0,358 & 0,396 & $\mathrm{TV}$ \\
\hline
\end{tabular}

\begin{tabular}{|l|l|l|l|}
17 & 0,431 & 0,396 & $\mathrm{~V}$ \\
\hline 18 & 0,447 & 0,396 & $\mathrm{~V}$ \\
\hline 19 & 0,438 & 0,396 & $\mathrm{~V}$ \\
\hline 20 & 0,398 & 0,396 & $\mathrm{~V}$ \\
\hline 21 & 0,463 & 0,396 & $\mathrm{~V}$ \\
\hline 22 & 0,472 & 0,396 & $\mathrm{~V}$ \\
\hline 23 & 0,544 & 0,396 & $\mathrm{~V}$ \\
\hline 24 & 0,498 & 0,396 & $\mathrm{~V}$ \\
\hline 25 & 0,497 & 0,396 & $\mathrm{~V}$ \\
\hline 26 & 0,397 & 0,396 & $\mathrm{~V}$ \\
\hline 27 & 0,457 & 0,396 & $\mathrm{~V}$ \\
\hline 28 & 0,547 & 0,396 & $\mathrm{~V}$ \\
\hline 29 & 0,384 & 0,396 & $\mathrm{TV}$ \\
\hline 30 & 0,463 & 0,396 & $\mathrm{~V}$ \\
\hline
\end{tabular}

Berdasarkan Tes Reliabilitas dengan Alpha Cronbach Penguasaan Kosakata Baku $\left(\mathrm{X}_{2}\right)$

\begin{tabular}{|c|c|}
\hline \multicolumn{2}{|c|}{ Reliability Statistics } \\
\hline Cronbach's Alpha & N of Items \\
\hline .896 & 30 \\
\hline
\end{tabular}

Note: $r$-tabel $=0,396 ; \mathrm{db}=25 ; \alpha=0,05$

Dari uraian di atas, jumlah item uji validitas untuk variabel Minat Belajar $\left(X_{1}\right)=26$ item dan variabel Penguasaan Kosakata $\left(\mathrm{X}_{2}\right)=24$ item. Hasil uji validitas terhadap variabel penelitian terhadap 60 item pernyataan, dinyatakan 50 valid dan 10 drop (tidak valid). Hasil uji reliabilitas yang dilakukan memperlihatkan bahwa reliabilitas kuesioner variabel Minat Belajar $\left(\mathrm{X}_{1}\right)$ adalah $=0,883$ dan reliabilitas kuesioner variabel Penguasaan Kosakata $\left(\mathrm{X}_{2}\right)$ sebesar $=0,896$. Jadi, item yang valid dan reliabel serta layak untuk digunakan dalam menjaring data penelitian menjadi 50 item. Berikut adalah rincian

Sebelum dan Sesudah Uji Coba

\begin{tabular}{|l|c|c|c|}
\hline \multicolumn{1}{|c|}{ Jenis Instrumen } & $\mathrm{X}_{1} /$ Reliabilitas & $\mathrm{X}_{2} /$ Reliabilitas & Jumlah \\
\hline Sebelum Uji Coba / Validasi & $30 / 0,883$ & $30 / 0,896$ & 60 soal \\
& & & 10 soal \\
\hline Item Tidak Valid & 4 & 24 & 50 soal \\
\hline Sesudah Uji Coba & 26 & & \\
& & & \\
\hline
\end{tabular}

Dalam analisis deskriptif data disajikan dalam bentuk tabel distribusi frekuensi maupun histogram, selanjutnya dihitung nilai rata-rata, median, modus, dan simpangan baku. Adapun langkah-langkah pembuatan tabel distribusi frekuensi dilakukan dengan langkah-langkah sebagai berikut (Supardi, 2012: 35-36):

a. Mengurutkan data dari terkecil sampai terbesar.

b. Menghitung jarak atau rentangan (R), yaitu data tertinggi dikurangi data terendah.

c. Menghitung jumlah kelas $(\mathrm{K})$ dengan rumus $\mathrm{K}=1+3,3 \log \mathrm{n}$

d. Menghitung panjang interval $(\mathrm{P})$, dengan rumus:

$$
P=\frac{\text { rentang }(R)}{\text { jumlah kelas }(K)}
$$

e. Menentukan ujung data pertama kemudian menghitug kelas interval dengan menjumlahkan ujung bawah kelas sampai pada data akhir.

f. Membuat tabel sementara dengan cara dihitung satu demi satu yang sesuai dengan urutan interval kelas 
g. Membuat tabel distribusi frekuensi dengan cara memindahkan semua angka frekuensi. Sedangkan ukuran nilai pusat letak dapat ditentukan dengan langkah-langkah berikut:

a. Menentukan rerata (mean).

b. Menentukan median (Me)

c. Menentukan modus (Mo)

Dan untuk ukuran simpangan dapat dditentukan dengan langkah-langkah berikut:

a. Menentukan rentangan (R).

b. Menentukan varian.

c. Menentukan simpangan baku.

Sebelum melakukan analisis lebih lanjut, terlebih dahulu dilakukan uji persyaratan analisis, yaitu uji normalitas dilakukan untuk mengetahui data yang diperoleh berdistribusi normal atau tidak dengan menggunakan uji Liliofors ( $\mathrm{L}_{\text {hitung }}$ ) dengan bantuan perhitungan program SPSS versi 20. Pengujian dilakukan dengan menggunakan taraf signifikasi 0,05 . Data dinyatakan normal jika signifikasi lebih besar dari 0,05 .

\section{Hasil dan Diskusi}

Nilai minat belajar siswa yang diperoleh dari para responden mempunyai rata-rata (mean) $=107,85$, median $=107,00$, modus $($ mode $)=102$, dengan simpangan baku (standar deviasi) sebesar $=8,104$, skor minimum $=86$, skor maksimum $=123$, serta range skor $=37$. Dari deskripisi tersebut, dapat dilihat bahwa antara nilai rata-rata dan median hampir sama, yakni 107,85 dan 107,00. Hal ini menunjukkan bahwa data skor minat pada penelitian ini cukup representatif. Selain itu, skor minat belajar yang lebih tinggi dibanding dengan median menunjukkan bahwa lebih banyak siswa yang memiliki minat belajar lebih tinggi dibandingkan dengan yang memiliki minat belajar rendah. Menurut statistik modus, mayoritas skor minat belajar adalah 102. Skor simpangan baku adalah 8,104 menunjukkan perbedaan minat belajar responden termasuk tinggi. Hal ini menunjukkan bahwa skor minat belajar bahasa Indonesia dari responden termasuk paling beragam di bawah variabel Kemampuan Menulis Deskripsi (Y) 9,331 dan di atas variabel Penguasaan Kosakata Baku $\left(\mathrm{X}_{2}\right)$ 3,662. Untuk lebih jelasnya, data dilihat dari tabel di bawah ini.

\section{Tabel 5}

\begin{tabular}{|l|c|c|c|}
\hline \multicolumn{2}{|c|}{ Statistics } \\
\hline \multirow{2}{*}{$\mathrm{N}$} & Minat Belajar & $\begin{array}{c}\text { Penguasaan } \\
\text { Kosakata Baku }\end{array}$ & $\begin{array}{c}\text { Kemampuan } \\
\text { Menulis Deskripsi }\end{array}$ \\
\hline Mean & & 80 & 80 \\
\hline Median & 80 & 0 & 0 \\
\hline Mode & 0 & 17.14 & 76.46 \\
\hline Std. Deviation & 107.85 & 17.00 & 75.00 \\
\hline Skewness & 107.00 & 18 & 70 \\
\hline Std. Error of Skewness & 102 & 3.662 & 9.331 \\
\hline Kurtosis & 8.104 & -.582 & -.184 \\
\hline Std. Error of Kurtosis & .058 & .269 & .269 \\
\hline Range & .269 & 1.112 & -.519 \\
\hline Minimum & -.298 & .532 & .532 \\
\hline Maximum & .532 & 19 & 42 \\
\hline
\end{tabular}

Dilihat dari distribusi, variabel Minat Belajar $\left(\mathrm{X}_{1}\right)$ mempunyai distribusi menceng ke kanan, yang ditandai dengan angka statistik skewness positif $=0,058$ dan jika dilihat keruncingan atau kurtosis menunjukkan bahwa variabel Minat Belajar $\left(\mathrm{X}_{1}\right)$ cenderung lebih runcing yang ditunjukkan dengan nilai kurtosis yang negatif sebesar $=-0,298$.

Skor Penguasaan Kosakata Baku $\left(\mathrm{X}_{2}\right)$ siswa yang diperoleh dari para responden mempunyai ratarata $($ mean $)=17,14$, median $=17,00$, modus $($ mode $)=18$, dengan simpangan baku $($ standar deviasi $)=$ 3,662 , skor minimum $=5$, skor maksimum $=24$, serta range skor $=19$. Dari deskripisi tersebut, dapat dilihat bahwa antara nilai rata-rata dan median hampir sama, yakni 17,14 dan 17,00. 
Hal ini menunjukkan bahwa data skor Penguasaan Kosakata Baku $\left(\mathrm{X}_{2}\right)$ pada penelitian ini cukup representatif. Selain itu, skor minat belajar yang lebih tinggi dibanding dengan median menunjukkan bahwa lebih banyak siswa yang memiliki Penguasaan Kosakata Baku lebih tinggi dibandingkan dengan yang memiliki Penguasaan Kosakata Baku rendah. Menurut statistik modus, mayoritas skor Penguasaan Kosakata Baku adalah 18. Skor simpangan baku adalah 3,662 menunjukkan perbedaan Penguasaan Kosakata Baku $\left(\mathrm{X}_{2}\right)$ responden termasuk tinggi. Hal ini menunjukkan bahwa skor Penguasaan Kosakata Baku $\left(\mathrm{X}_{2}\right)$ dari responden termasuk beragam di bawah variabel Kemampuan Menulis Teks Deskriptif (Y) $=9,331$ dan variabel Minat Belajar $\left(X_{1}\right)=8,104$.

Dilihat dari distribusi menunjukkan bahwa variabel Penguasaan Kosakata Baku $\left(\mathrm{X}_{2}\right)$ mempunyai distribusi menceng ke kiri, yang ditandai dengan angka statistik skewness negatif $=-0.582$ dan jika dilihat keruncingan atau kurtosis menunjukkan bahwa variabel Penguasaan Kosakata Baku cenderung lebih runcing yang ditunjukkan dengan nilai kurtosis yang positif sebesar $=1,112$.

Skor Kemampuan Menulis Deskripsi (Y) siswa yang diperoleh dari para responden mempunyai rata-rata $($ mean $)=76,46$, median 75,00, modus $($ mode $)=70$, dengan simpangan baku (standar deviasi) sebesar $=9,331$, skor minimum $=50$, skor maksimum $=92$, serta range skor $=42$. Dari deskripisi tersebut, dapat dilihat bahwa antara nilai rata-rata dan median hampir sama, yakni 76,46 dan 75,00. Hal ini menunjukkan bahwa data skor Kemampuan Menulis Teks Deskriptif (Y) pada penelitian ini cukup representatif. Selain itu, skor rata-rata (mean) Kemampuan Menulis Deskripsi (Y) lebih tinggi dibanding dengan median menunjukkan bahwa lebih banyak siswa yang memiliki Kemampuan Menulis Deskripsi (Y) lebih tinggi dibandingkan dengan yang memiliki Kemampuan Menulis Deskripsi (Y) rendah. Menurut statistik modus, mayoritas skor Kemampuan Menulis Deskripsi (Y) adalah 70. Skor simpangan baku adalah 9,331 menunjukkan perbedaan Kemampuan Menulis Deskripsi (Y) responden termasuk paling tinggi. Hal ini menunjukkan bahwa skor Kemampuan Menulis Deskripsi (Y) dari responden termasuk beragam di atas variabel Minat Belajar $\left(\mathrm{X}_{1}\right)$ 8, 104 dan variabel Penguasaan Kosakata Baku $\left(\mathrm{X}_{2}\right)$ 3, 662.

Dilihat dari distribusi menunjukkan bahwa variabel Kemampuan Menulis Deskripsi (Y) mempunyai distribusi menceng ke kiri, yang ditandai dengan angka statistik skewness negatif $=-0,184$ dan jika dilihat keruncingan atau kurtosis menunjukkan bahwa variabel Kemampuan Menulis Deskripsi (Y) lebih runcing yang ditunjukkan dengan nilai kurtosis yang negatif sebesar $=-0,519$.

Pengujian persyaratan analisis data yang dilakukan dalam penelitian ini adalah pengujian normalitas dan linieritas garis regresi parsial antara variabel bebas dan variabel terikat.

$\mathrm{H}_{\mathrm{o}} \quad$ = sampel berdistribusi normal

$\mathrm{H}_{1} \quad$ = sampel tidak berdistribusi normal

Dengan kriteria pengujian:

Jika $\mathrm{a}_{\max }>\mathrm{D}_{\text {tabel }}: \mathrm{H}_{\mathrm{o}}$ ditolak

Jika $\mathrm{a}_{\max }<\mathrm{D}_{\text {tabel }}: \mathrm{H}_{\mathrm{o}}$ diterima

Rangkuman dari data hasil uji normalitas menggunakan program olah data SPSS versi 20 for windows

\begin{tabular}{|c|c|c|c|c|}
\hline \multicolumn{5}{|c|}{ One-Sample Kolmogorov-Smirnov Test } \\
\hline & & Minat Belajar & $\begin{array}{c}\text { Penguasaan } \\
\text { Kosakata Baku }\end{array}$ & $\begin{array}{c}\text { Kemampuan } \\
\text { Menulis Teks } \\
\text { Deskriptif }\end{array}$ \\
\hline \multicolumn{2}{|l|}{$\mathrm{N}$} & 80 & 80 & 80 \\
\hline \multirow{2}{*}{ Normal Parameters ${ }^{\mathrm{a}, \mathrm{b}}$} & Mean & 107.85 & 17.14 & 76.46 \\
\hline & Std. Deviation & 8.104 & 3.662 & 9.331 \\
\hline \multirow{3}{*}{ Most Extreme Differences } & Absolute & .120 & .105 & .120 \\
\hline & Positive & .120 & .094 & .112 \\
\hline & Negative & -.062 & -.105 & -.120 \\
\hline \multicolumn{2}{|l|}{ Kolmogorov-Smirnov Z } & 1.075 & .937 & 1.072 \\
\hline \multicolumn{2}{|l|}{ Asymp. Sig. (2-tailed) } & .198 & .344 & .200 \\
\hline
\end{tabular}

Dari tabel di atas, pada kolom minat belajar bahasa Indonesia $\left(\mathrm{X}_{1}\right)$, terdapat nilai KolmogorovSmirnov= 1,075 dengan probabilitas 0,198 (Asymp. Sig. (2-tailed)). Persyaratan data berdistribusi normal jika probabilitas atau $p>0,05$ pada uji normalitas Kolmogorov Smirnov. Jadi, karena nilai $p=0,198$ atau $p$ $>0,05$ maka $\mathrm{H}_{0}$ diterima dan $\mathrm{H}_{1}$ ditolak. Artinya, data Minat Belajar $\left(\mathrm{X}_{1}\right)$ berasal dari populasi yang berdistribusi normal. 
Pada kolom penguasaan kosakata baku $\left(\mathrm{X}_{2}\right)$, terdapat nilai Kolmogorov-Smirnov $=0,937$ dengan probabilitas 0,344 (Asymp. Sig. (2-tailed)). Persyaratan data berdistribusi normal jika probabilitas atau $p>$ 0,05 pada uji normalitas Kolmogorov Smirnov. Jadi, karena nilai $p=0,344$ atau $p>0,05$ maka $\mathrm{H}_{0}$ diterima dan $\mathrm{H}_{1}$ ditolak. Artinya, data Penguasaan Kosakata Baku $\left(\mathrm{X}_{2}\right)$ berasal dari populasi yang berdistribusi normal.

Pada kolom kemampuan menulis deskripsi (Y), terdapat nilai Kolmogorov Smirnov = 1,072 dengan probabilitas 0,2 (Asymp. Sig. (2-tailed)). Persyaratan data berdistribusi normal jika probabilitas atau $p>$ 0,05 pada uji normalitas Kolmogorov Smirnov. Jadi, karena nilai $p=0,2$ atau $p>0,05$ maka $\mathrm{H}_{0}$ diterima dan $\mathrm{H}_{1}$ ditolak. Artinya, data kemampuan menulis deskripsi $(\mathrm{Y})$ berasal dari populasi yang berdistribusi normal. Dengan demikian, disimpulkan bahwa data dalam penelitian ini berasal dari populasi yang berdistribusi normal. Hal ini menunjukkan bahwa salah satu prasyaratan uji $\mathrm{F}$ dalam penelitian ini telah terpenuhi.

Selanjutnya adalah peneliti melakukan pengujian multikolinieritas. Pengujian ini bertujuan untuk mengetahui apakah model regresi ditemukan adanya korelasi yang sempurna antarvariabel bebas (independen) atau tidak. Model regresi yang baik seharusnya tidak terjadi korelasi yang sempurna di antara variabel bebas. Cara mendeteksi adanya multikolinieritas adalah dengan melihat Tolerance (TOL) atau Varian Inflation Faktor (VIF). Apabila TOL $<0,1$ atau VIF $>10$ maka terjadi multikolinieritas.

Hasil uji multikolinieritas yang dilakukan dengan bantuan komputer program SPSS 20 adalah sebagai berikut.

Hasil Uji Multikolonieritas TOL dan VIF

Coefficients $^{\mathrm{a}}$

\begin{tabular}{|l|l|c|c|}
\hline \multicolumn{1}{|c|}{ Model } & \multicolumn{2}{c|}{ Collinearity Statistics } \\
\hline \multirow{3}{*}{1} & Constant) & Tolerance & VIF \\
\cline { 2 - 4 } & Minat Belajar & .990 & 1.010 \\
\cline { 2 - 4 } & Penguasaan Kosakata Baku & .990 & 1.010 \\
\cline { 2 - 4 } & \multicolumn{2}{|c|}{} \\
\hline
\end{tabular}

a. Dependent Variabel: Kemampuan Menulis Deskripsi

Tabel di atas menunjukkan bahwa kedua variabel independent tidak terdapat multikolinieritas karena TOL 0,990 > 0,1 dan nilai VIF 1,010 < 10. Jadi, kedua variabel bebas (Variabel Minat Belajar dan Variabel Penguasaan Kosakata Baku) tidak ada multikolinieritas sehingga analisis regresi dapat dipergunakan lebih lanjut.

Hasil Perhitungan Koefisien Korelasi Pengaruh Variabel $\mathrm{X}_{1}$ dan $\mathrm{X}_{2}$ terhadap Variabel $\mathrm{Y}$

\begin{tabular}{|c|c|c|c|c|}
\hline \multicolumn{5}{|c|}{ Model Summary $^{\mathrm{b}}$} \\
\hline & $\mathrm{R}$ & R Square & Adjusted R Square & Std. Error of the Estimate \\
\hline 1 & $.602^{\mathrm{a}}$ & .363 & .346 & 7.545 \\
\hline a. Predictors: (Constant), Penguasaan Kosakata Baku, Minat Belajar & \\
\hline
\end{tabular}

Dari tabel di atas, terlihat bahwa koefisien korelasi ganda pengaruh variabel bebas Minat Belajar $\left(\mathrm{X}_{1}\right)$ dan Penguasaan Kosakata Baku $\left(\mathrm{X}_{2}\right)$ secara bersama-sama terhadap Prestasi Belajar Bahasa Indonesia pada Materi Kemampuan Menulis Deskripsi (Y) adalah sebesar 0,602. Dari perhitungan tersebut, dapat diketahui bahwa koefisien korelasi tersebut signifikan variabel bebas Minat Belajar $\left(\mathrm{X}_{1}\right)$ dan Penguasaan Kosakata Baku $\left(\mathrm{X}_{2}\right)$ secara bersama-sama terhadap Prestasi Belajar Bahasa Indonesia pada Materi Kemampuan Menulis Deskripsi (Y).

Koefisien determinasi adalah angka pada kolom $R$ squre pada kolom tabel di atas dikalikan $100 \%$ yang menunjukkan besarnya kontribusi pengaruh variabel bebas $\mathrm{X}_{1}$ dan $\mathrm{X}_{2}$ terhadap variabel terikat $\mathrm{Y}$. Berdasarkan hasil tersebut, dalam penelitian ini diperoleh koefisien determinasinya sebesar 36,3\% yang menunjukkan bahwa besarnya kontribusi Minat Belajar $\left(\mathrm{X}_{1}\right)$ dan Penguasaan Kosakata Baku $\left(\mathrm{X}_{2}\right)$ secara bersama-sama terhadap Prestasi Belajar Bahasa Indonesia pada Materi Kemampuan Menulis Deskripsi (Y) adalah sebesar $36,3 \%$, sedangkan sisanya $(63,7 \%)$ karena pengaruh faktor lain. 
Selanjutnya, jika dikaji lebih lanjut berdasarkan koefisien korelasi parsial, ada korelasi antara variabel dependent dengan salah satu variabel independent setelah pengaruh hubungan linier variabelvariabel independen lainnya dibilangkan.

\begin{tabular}{|l|l|r|r|r|r|r|}
\hline \multicolumn{7}{|c|}{ ANOVA $^{\mathrm{a}}$} \\
\hline Model & Sum of Squares & df & Mean Square & F & Sig. \\
\hline \multirow{3}{*}{1} & Regression & 2494.477 & 2 & 1247.238 & 21.909 & $.000^{\mathrm{b}}$ \\
\cline { 2 - 7 } & Residual & 4383.411 & 77 & 56.927 & & \\
\cline { 2 - 7 } & Total & 6877.888 & 79 & & & \\
\hline
\end{tabular}

Pengujian signifikansi garis regresi yang ada pada tabel ANOVA di atas menunjukkan bahwa nilai Sig. $=0,000$, sedangkan nilai $F_{\text {hitung }}=21,909$. Nilai $F_{\text {tabel }}=3,115$. Karena nilai Sig. $<0,05$ dan $F_{\text {hitung }}>F$ tabel maka $\mathrm{H}_{0}$ ditolak dan $\mathrm{H}_{1}$ diterima. Hal ini berarti bahwa koefisien regresi tersebut signifikan.

Dari hasil pengujian korelasi maupun regresi tersebut, dapat disimpulkan bahwa terdapat pengaruh positif yang signifikan variabel bebas minat belajar $\left(\mathrm{X}_{1}\right)$ dan penguasaan kosakata baku $\left(\mathrm{X}_{2}\right)$ secara bersama-sama terhadap variabel terikat prestasi belajar bahasa Indonesia pada materi kemampuan menulis deskripsi siswa (Y).

Rekapitulasi Hasil Perhitungan Garis Regresi Pengaruh

Variabel $\mathrm{X}_{1}$ dan $\mathrm{X}_{2}$ terhadap Variabel $\mathrm{Y}$

Coefficients $^{\mathrm{a}}$

\begin{tabular}{|c|l|c|c|c|c|c|}
\hline \multicolumn{2}{|c|}{ Model } & \multicolumn{2}{|l|}{ Unstandardized Coefficients } & \multirow{2}{*}{$\begin{array}{c}\text { Standardized } \\
\text { Coefficients }\end{array}$} & \multirow{2}{*}{ Sig. } \\
\cline { 3 - 7 } \multicolumn{2}{|c|}{} & B & Std. Error & Beta & & \\
\hline \multirow{3}{*}{1} & (Constant) & 12.397 & 12.439 & & .997 & .322 \\
\cline { 2 - 7 } & Minat Belajar & .375 & .105 & .326 & 3.564 & .001 \\
\cline { 2 - 7 } & Penguasaan Kosakata Baku & 1.377 & .233 & .540 & 5.909 & .000 \\
\hline
\end{tabular}

Pada data statistik, ditunjukkan bahwa variabel minat belajar $\left(\mathrm{X}_{1}\right)$ mempunyai nilai $\mathrm{t}_{\text {hitung }}=3,564$, sedangkan untuk variabel penguasaan kosakata baku $\left(\mathrm{X}_{2}\right) \mathrm{t}_{\text {hitung }}=5,909$. Nilai Sig. pada variabel minat belajar $\left(\mathrm{X}_{1}\right)$ adalah 0,001, sedangkan nilai Sig. pada variabel penguasaan kosakata baku $\left(\mathrm{X}_{2}\right)$ adalah 0,000.

Nilai $t_{\text {hitung }} \mathrm{X}_{1}<\mathrm{t}_{\text {hitung }} \mathrm{X}_{2}$ dan nilai Sig. $\mathrm{X}_{1}>$ Sig. $\mathrm{X}_{2}(0,001>0,000)$. Hal ini menunjukkan bahwa pengaruh variabel penguasaan kosakata baku $\left(\mathrm{X}_{2}\right)$ terhadap prestasi belajar bahasa Indonesia pada materi kemampuan menulis deskripsi $(\mathrm{Y})$ lebih signifikan dibanding dengan pengaruh variabel minat belajar $\left(\mathrm{X}_{1}\right)$.

Kedua variabel bebas, minat belajar $\left(\mathrm{X}_{1}\right)$ dan penguasaan kosakata baku $\left(\mathrm{X}_{2}\right)$, secara bersama-sama berpengaruh positif terhadap prestasi belajar bahasa Indonesia pada materi menulis teks deskriptif. Akan tetapi, dari data di atas, dapat disimpulkan bahwa pengaruh penguasaan kosakata baku $\left(\mathrm{X}_{2}\right)$ lebih besar atau lebih signifikan dibandingkan dengan pengaruh minat belajar $\left(\mathrm{X}_{1}\right)$ terhadap prestasi belajar bahasa Indonesia pada materi menulis teks deskriptif.

\section{Simpulan}

Terdapat pengaruh yang signifikan variabel minat belajar (X1) dan variabel penguasaan kosakata baku (X2) secara bersama-sama terhadap prestasi belajar bahasa Indonesia pada materi kemampuan menulis teks deskriptif (Y). Hal ini dibuktikan dengan Fhitung $=21,909$ dan nilai Sig. $=0,000<0,05$. Nilai koefisien korelasi atau hubungan positif yang ditunjukkan dengan skor ry $1=0,602$, sedangkan kekuatan sumbangan ditunjukkan dengan koefisien determinasi $(\mathrm{r} 2)=0,363$ yang menunjukkan bahwa variabel minat belajar (X1) dan variabel penguasaan kosakata baku (X2) secara bersama-sama memberikan konstribusi sebesar 36,3\% terhadap variabel prestasi belajar bahasa Indonesia pada materi kemampuan menulis teks deskriptif (Y).

Terdapat pengaruh yang signifikan variabel minat belajar (X1) terhadap prestasi belajar bahasa Indonesia pada materi kemampuan menulis teks deskriptif $(\mathrm{Y})$. Hal ini dibuktikan dengan thitung $=3,564$ dan nilai Sig. $=0,001<0,05$.

Terdapat pengaruh yang signifikan variabel penguasaan kosakata baku (X2) terhadap prestasi belajar bahasa Indonesia pada materi kemampuan menulis teks deskriptif (Y). Hal ini dibuktikan dengan thitung $=5,909$ dan nilai Sig. $=0,000<0,05$. 
Dengan demikian, minat belajar dan penguasaan kosakata baku berperan sangat penting dalam menentukan dan meningkatkan prestasi belajar bahasa Indonesia khususnya pada materi kemampuan menulis teks deskriptif siswa. Berdasarkan temuan penelitian pada analisis data penelitian di atas, prestasi belajar bahasa Indonesia pada materi kemampuan menulis teks deskriptif siswa dapat menjadi lebih baik dengan cara meningkatkan minat belajar dan penguasaan kosakata baku.

\section{Ucapan Terima Kasih}

Peneliti mengucapkan terima kasih kepada Kepala SMPN 1 Depok dan SMAN 2 Depok terima kasih atas kemudahannya dalam mengumpulkan data dalam pengerjaan penelitian ini. Selain itu, terima kasih pula kepada semua pihak yang membantu penulis dalam menyelesaikan artikel hasil riset ini sehingga bisa diterbitkan di Jurnal Hortatori.

\section{Daftar Rujukan}

Akhadiah, Sabarti, et al. Pembinaan Kemampuan Menulis Bahasa Indonesia. Jakarta: Erlangga. 1993. Print.

Arikunto, Suharsimi, Prosedur Penelitian Suatu Pendekatan Praktek. Jakarta: Rineka Cipta. 2010. Print.

Badudu, J.S. dan Muhammad Zain. Kamus Umum Bahasa Indonesia. Jakarta: Pustaka Sinar Harapan. 1996. Print.

Keraf, Gorys. Argumentasi dan Narasi. Jakarta: PT Gramedia Pustaka Utama. 2007. Print.

Mapiere, Andi. Psikologi Orang Dewasa. Surabaya: Usaha Nasional. 1992. Print.

Moeliono, Anton M., et al. Tata Bahasa Baku Bahasa Indonesia. Jakarta: Balai Pustaka. 1989. Print.

Mulyasa, E. Kurikulum Berbasis Kompetensi. Bandung: Remaja Rosda Karya. 2002. Print.

Soekamto, Toeti. Validitas Instrumen Pengukuran di Kawasan Afektif. Jakarta: LPP IKIP. 1991. Print.

Semi, M. Atar.. Dasar-Dasar Keterampilan Menulis. Bandung: Angkasa, 2007. Print.

Sugiono. Metode Penelitian Pendidikan. Bandung: Alfabeta. 2008. Print.

Sugiono.Metode Penelitian Bisnis. Bandung: Alfabeta. 2012. Print.

Suherli. Menulis Karangan Ilmiah. Depok: Arya Duta. 2007. Print.

Sudijono, Anas. Pengantar Statistik 2Pendidikan. Jakarta: PT. Raja Grafindo Persada. 2010. Print.

Tarigan, Henry Guntur. Menulis sebagai Suatu Keterampilan Berbahasa.

Bandung: Angkasa. 2008. Print.

Zaimar, Okke Kusuma Sumantri dan Ayu Basoeki Harahap. Telaah

Wacana: Teori dan Penerapannya. Depok: Komodo Book. 2011. Print. 